\title{
Keterampilan Manajerial Kepala Sekolah Dasar Inpres di Kecamatan Duampanua Kabupaten Pinrang
}

\author{
Nurfadillah, Andi Mappincara, Andi Wahed* \\ Universitas Negeri Makassar, Makasar, Sulawesi Selatan, Indonesia \\ Corresponding author: Andi Wahed (e-mail: andi.wahed@unm.ac.id)
}

\begin{abstract}
Abstrak: Penelitian ini mengkaji tentang peran manajerial kepala sekolah dalam peningkatan mutu di sekolah dasar (SD). Metode penelitian yang digunakan dalam penelitian ini adalah metode kualitatif. Sumber data penelitian ini yaitu kepala sekolah dan guru. Teknik pengumpulan data melalui wawancara, observasi, dan dokumentasi. Teknik analisis data menggunakan model Miles, Huberman, dan Saldana yang meliputi pengumpulan, kondensasi, penyajian, dan verifikasi data. Keabsahan data dicapai melalui trianggulasi sumber dan teknik. Hasil penelitian menunjukkan: 1) keterampilan konsep yaitu menyusun visi, misi, tujuan, dan sasaran sekolah, 2) keterampilan teknis yaitu perencanaan, pengaturan, koordinasi, pengawasan dan pengendalian, 3) kemampuan membangun hubungan yaitu motivasi yaitu dengan cara memberikan penghargaan bagi guru yang berprestasi dan menanamkan semangat kerja.
\end{abstract}

Kata Kunci: manajerial kepala sekolah, mutu sekolah

\section{Primary School Principal Managerial Skills in SD Inpres Tantu Kecamatan Duampanua, Pinrang District}

\begin{abstract}
This study examines the managerial skills of the primary schoolprincipals consisting of conceptual, human relation, and technical skills. This is a qualitative study. The data sources are principals and teachers. Data were collected through interviews, observations, and documentation. The Miles, Huberman, and Saldana model of qualitative data analysis was applied to analyse data. The data validity is achieved through triangulation using different data sources. The results showed that 1) conceptual skills performed by the principals include developing the school vision, mission, and objectives; 2) technical skills performed by the principals include planning, organizing, coordinating, supervision, and control the school programs, 3) the ability to develop relationships with people performed by the principals include giving rewards to teachers who are excel and instill the work spirit to others.
\end{abstract}

Keywords: principal's managerial, school quality 


\section{PENDAHULUAN}

Pendidikan adalah pembelajaran pengetahuan, keterampilan, dan kebiasaan sekelompok orang yang diturunkan dari satu generasi ke generasi berikutnya melalui pengajaran, pelatihan, dan penelitian. Pendidikan dapat terjadi melalui bimbingan orang lain maupun otodidak. Selain itu, pendidikan dapat dilakukan di mana pun. Maksudnya, pendidikan dapat dilakukan tidak hanya di sekolah namun juga di lingkungan keluarga, masyarakat, bahkan alam. Pendidikan dapat diartikan sebagai sistem proses belajar mengajar yang dilakukan secara sadar, rasional, terencana, terjadwal, metodik, sistemik, dan sistematis untuk mencapai tujuan.

Tugas utama sekolah adalah mendidik dengan cara membina, membimbing, melatih dan mengarahkan peserta didik. Ditinjau dari posisi dan fungsinya, sekolah adalah lanjutan dari pendidikan keluarga dan berfungsi sebagai jembatan antara kehidupan keluarga dan kehidupan masyarakat. Menurut posisi dan fungsinya berarti sekolah bertanggung jawab pada peserta didik sebagai generasi muda agar mampu memajukan kehidupan keluarga dan masyarakat di masa depan. Undang-Undang Nomor 20 Tahun 2003 tentang Sistem Pendidikan Nasional, menjelaskan bahwa sekolah adalah wahana yang dilalui peserta didik untuk mengembangkan potensi diri dalam suatu proses pendidikan yang sesuai dengan tujuan Pendidikan.

Pendidikan bermutu merupakan suatu proses yang derajat keefektifannya beragam yang terjadi di sekolah. Peningkatan mutu sekolah merupakan usaha yang terus menerus. Menarik untuk diamati bahwa banyak sekolah yang terbukti tidak berhasil meningkatkan mutu karena tidak fokus pada prinsip-prinsip pencapaian mutu. Cara menentukan sebuah program pendidikan bermutu atau tidak adalah dengan cara melihat asal dan arah tujuan program. Meskipun telah banyak perhatian difokuskan pada isi dan metodologi pengajaran, namun terkadang mutu sekolah tidak sesuai dengan harapan sekolah.

Fenomena ini menunjukkan pentingnya intuisi dan kreativitas kepala sekolah sebagai penentu strategi. Kemampuan itu dapat mengantisipasi setiap perubahan lingkungan agar dapat bertahan dan menang bersaing. Hal ini merupakan bentuk kristalisasi kegiatan dalam merealisasikan sasaran yang komprehensif. Diketahui bahwa tugas pokok seorang kepala sekolah berdasarkan Permendikbud Nomor 6 Tahun 2018 Tentang Penugasan Guru sebagai kepala sekolah yaitu sebagai pengembang jiwa kewirausahaan, supervisi, dan manajerial. Penelitian ini mengkaji peran manajerial kepala sekolah dalam peningkatan mutu sekolah. Peran manajerial kepala sekolah merupakan kemampuan kepala sekolah dalam menyusun program, menyusun organisasi kepegawaian di sekolah, menggerakkan staf serta mengoptimalkan sumber daya sekolah. Lebih spesifik, penelitian ini memfokuskan pada 
keterampilan konsep, keterampilan teknis/operasional, dan keterampilan hubungan manusia dalam peningkatan mutu sekolah di Sekolah Dasar Instruksi Presiden (SD Inpres) Tantu Kecamatan Duampanua Kabupaten Pinrang, Provinsi Sulawesi Selatan.

\subsection{Peran manajerial kepala sekolah}

Peran manajerial kepala sekolah menurut Katz dan Kahn (dalam Atmodiwirio, 2014:7) bahwa keterampilan manajerial itu meliputi tiga aspek utama: (1) keterampilan konseptual, menekankan pengetahuan dan teknis terkait standar nasional pendidikan (SNP), (2) keterampilan teknis, mencakup teknik proses manajemen (perencanaan, pengaturan, koordinasi, pengawasan, dan pengendalian), (3) manusia, kemampuan membangun hubungan antar manusia, memotivasi dan membangun moral.

Keterampilan konsep adalah keterampilan seorang manajer dalam konsep pemikiran, ide, gagasan yang sangat berguna bagi penyusunan rencana dan pemecahan masalah. Menurut Payol (dalam Atmodiwirio, 2014) keterampilan konseptual adalah kemampuan untuk mengkoordinasikan dan mengintegrasikan semua kepentingan dan aktivitas organisasi. Keterampilan teknis adalah kemampuan manusia untuk menggunakan prosedur, teknis, dan pengetahuan mengenai bidang khusus (Atmodiwirio, 2014). Keterampilan teknis ini merupakan kemampuan untuk menjalankan suatu pekerjaan tertentu yang mencakup perencanaan, pengaturan, koordinasi, pengawasan, dan pengendalian.

Kemampuan membangun hubungan adalah kemampuan seorang manajer untuk berinteraksi dengan orang lain dengan memberikan motivasi dan membangun semangat moral. Motivasi menurut Mulyasa (2005) adalah “tenaga pendorong atau penarik yang menyebabkan adanya tingkah laku ke arah suatu tujuan tertentu. Seseorang akan bersungguh-sungguh karena memiliki dorongan dan motivasi tinggi”. Selanjutnya, semangat/moral menurut Chaplin (1989) adalah "akhlak yang sesuai dengan peraturan sosial, menyangkut hukum atau adat kebiasaan yang mengatur tingkah laku atau sikap dan perbuatan setiap individu terhadapkehidupan orang lain".

\subsection{Mutu dalam perspektif standar nasional pendidikan}

Standar isi adalah adalah kriteria mengenai ruang lingkup materi dan tingkat kompetensi untuk mencapai kompetensi lulusan pada jenjang dan jenis pendidikan tertentu (PP No. 13 tahun 2015 
Bab 1 pasal 1 ayat 6). Dalam hal ini pada Undang-undang No 20 tahun 2003 tentang Sistem Pendidikan Nasional, pasal 1 ayat 9 disebutkan kurikulum adalah seperangkat rencana dan pengaturan mengenai tujuan, isi, dan bahan pelajaran serta cara yang digunakan sebagai pedoman penyelenggaraan kegiatan pembelajaran untuk mencapai tujuan pendidikan tertentu.

Standar proses adalah kriteria mengenai pelaksanaan pembelajaran pada satu satuan pendidikan untuk mencapai standar kompetensi lulusan (PP No. 13 tahun 2015 Bab 1 pasal 1 ayat 7). Selanjutnya standar proses adalah kriteria mengenai pelaksanaan pembelajaran pada satuan pendidikan untuk mencapai standar kompetensi lulusan. Standar proses dikembangkan mengacu pada standar kompetensi lulusan dan standar isi yang telah ditetapkan sesuai dengan ketentuan dalam Peraturan Pemerintah No. 19 tahun 2005 tentang Standar Nasional Pendidikan. Sesuai dengan prinsip pembelajaran yang digunakan, standar proses mencakup perencanaan proses pembelajaran, pelaksanaan proses pembelajaran, penilaian hasil pembelajaran dan pengawasan proses pembelajaran (Peraturan Menteri Pendidikan dan Kebudayaan Nomor 22 tahun 2016 tentang standar proses pendidikan dasar dan menengah).

Standar kompetensi lulusan adalah kriteria mengenai kualifikasi kemampuan lulusan yang mencakup sikap, pengetahuan, dan keterampilan (PP No. 13 tahun 2015 Bab 1 pasal 1 ayat 5). Selanjutnya standar kompetensi lulusan pendidikan dasar dan menengah digunakan sebagai acuan utama pengembangan standar isi, standar proses, standar penilaian, standar pendidik dan kependidikan, standar sarana dan prasarana, stand ar pengelolaan, dan standar pembiayaan (Permendikbud Nomor 20 tahun 2016 tentang Standar Kompetensi Lulusan Pendidikan Dasar dan Menengah pasal 1 ayat 1). Standar kompetensi lulusan yang dimaksud pada ayat 1 meliputi kompetensi lulusan SD/MI/SDLB/ Paket A, kompetensi lulusan SMP/MTS/ SMPLB/ PaketB, dan kompetensi lulusan SMA/MA/SMK/MAK/ SMALB / Paket C (Permendikbud Nomor 20 tahun 2016 tentang standar kompetensi lulusan pendidikan dasar dan menegah pasal 1 ayat 2 ).

Standar pendidik dan tenaga kependidikan adalah kriteria mengenai pendidikan prajabatan dan kelayakan fisik maupun mental, serta pendidikan dalam jabatan (PP No.13 tahun 2015 Bab 1 pasal 1 ayat 8). Selanjutnya, standar pendidik akan menentukan kualifikasi setiap guru sebagai tenaga profesional yang dapat menunjang keberhasilan pencapaian tujuan pendidikan. Asumsi yang mendasarinya adalah standar proses hanya dapat dilaksanakan manakala guru memiliki kualifikasi tertentu. Dengan demikian, tidak setiap orang bisa menjadi guru. Jabatan guru hanya dapat dipegang oleh orang-orang yang telah memiliki kualifikasi tertentu. 
Standar sarana dan prasarana adalah kriteria mengenai ruang belajar, tempat berolahraga, tempat beribadah, perpustakaan, laboratorium, bengkel kerja, tempat bermain, tempat berkreasi dan berekreasi serta sumber belajar lain yang diperlukan untuk menunjang proses pembelajaran, termasuk penggunaan teknologi informasi dan komunikasi (PP No.13 tahun 2015 Bab 1 pasal 1 ayat 9). Standar pengelolaan adalah kriteria mengenai perencanaan, pelaksanaan, dan pengawasan kegiatan pendidikan pada tingkat satuan pendidikan, kabupaten/kota, provinsi atau nasional agar tercapai efisiensi dan efektivitas penyelenggaraan pendidikan (PP No.13 tahun 2015 Bab 1 pasal 1 ayat 10). Standar pembiayaan adalah kriteria mengenai komponen dan besarnya biaya operasi satuan pendidikan yang berlaku selama satu tahun (PP No.13 tahun 2015 Bab 1 pasal 1 ayat 11). Standar penilaian adalah kriteria mengenai mekanisme prosedur dan instrumen penilaian hasil belajar peserta didik (PP No.13 tahun 2015 Bab 1 pasal 1 ayat 12).

\section{METODE PENELITIAN}

\subsection{Jenis penelitian}

Penelitian ini menggunakan pendekatan kualitatif berdasarkan beberapa pertimbangan. Penelitian ini bermaksud mengkaji peran manajerial kepala sekolah dalam peningkatan mutu sekolah di SD Inpres Tantu Kecamatan Duampanua Kabupaten Pinrang dengan menganalisis dan menaf sirkan suatu fakta yang menghasilkan data yang berupa hasil wawancara, observasi dan studi dokumen yang relevan.

\subsection{Kehadiran peneliti}

Instrumen utama penelitian ini adalah peneliti sendiri. Peneliti berusaha agar dapat menghindari pengaruh subjektivitas agar proses penelitian berjalan ideal. Peneliti tidak menentukan waktu penelitian karena peneliti menekankan pada keterlibatan langsung peneliti di lapangan dengan informan dan sumber data. Kehadiran peneliti secara langsung di lapangan sebagai tolak ukur keberhasilan untuk memahami kasus yang diteliti. Keterlibatan peneliti secara langsung dan aktif dengan informan mutlak perlu dilakukan semata-mata untuk mendapatkan data yang akurat. 


\subsection{Lokasi penelitian}

Lokasi yang dipilih adalah SD Inpres Tantu Kecamatan Duampanua Kabupaten Pinrang. Sekolah ini terletak di Kecamatan Duampanua, Kabupaten Pinrang, Provinsi Sulawesi Selatan.

\subsection{Sumber data dan pengumpulan data}

Subjek penelitian ini yaitu kepala sekolah SD Inpres dan guru kelas, guru olah raga dan guru agama yang banyak terlibat dalam kegiatan manajemen dengan kepala sekolah. Sesuai dengan karakteristik penelitian kualitatif, teknik pengumpulan data yang digunakan dalam penelitian ini adalah wawancara, observasi dan dokumentasi.

\subsection{Analisis data}

Analisis data penelitian ini dilakukan secara langsung, berkesinambungan dari awal sampai akhir proses penelitian. Dalam penelitian ini, proses analisis data dimulai dengan menelaah seluruh data yang diperoleh dari observasi, wawancara mendalam, dan dokumentasi. Penulis menganalisis data berdasarkan tahap analisis lapangan model Miles, Huberman dan Saldana (2014) yaitu pengumpulan data, kondensasi data, penyajian data, dan verifikasi data.

\subsection{Pengecekan keabsahan data}

Penelitian ini menggunakan triangulasi sebagai pengecekan keabsahan data. Menurut Moleong (2018), triangulasi dalam pengujian kredibilitas merupakan teknik pemeriksaan keabsahan data untuk keperluan pengecekan atau sebagai pembanding data dari berbagai sumber dengan cara dan waktu yang berbeda. Pada penelitian ini, triangulasi yang digunakan adalah triangulasi sumber dan triangulasi teknik. Tahapan dan proses penelitian yang dilalui yaitu tahap sebelum penelitian, penelitian, analisis data, dan penulisan laporan.

\section{HASIL}

\subsection{Keterampilan konsep}

Keterampilan konsep dibangun dengan menerjemahkan mutu dalam mencapai visi, misi, tujuan dan sasaran. Kepala sekolah membangun konsep mutu dengan menyusun target pencapaian standar yang digunakan sebagai acuan dalam rencana tindakan yang akan dilakukan. Selanjutnya, kepala sekolah melakukan perencanaan dengan bekerja sama dengan pemangku yang berkepentingan. Kepala sekolah membuat konsep perencanaan strategis untuk jangka waktu 4 tahun dengan melibatkan seluruh guru dan komite sekolah. Rencana ini 
selanjutnya diimplementasikan oleh seluruh stakeholders pendidikan dalam rangka pencapaian fungsi dan tujuan sekolah.

Dilihat dari pencapaiannya, SD inpres tantu yang sebelumnya terakreditasi B pada tahun 2009, pada tahun 2014 telah terakreditasi A. Sekolah bisa mencapai akreditasi A karena kepala sekolah mengadakan rapat penyusunan program kegiatan dan perencanaan tupoksi guru dan tugas tambahan lainnya dengan melibatkan semua pihak yang berkepentingan. Dengan kata lain, keterampilan konsep kepala sekolah telah mengarah pada pencapaian standar nasional pendidikan yaitu standar pengelolaan mengenai perencanaan, pelaksanaan, dan pengawasan kegiatan pendidikan pada tingkat satuan pendidikan.

\subsection{Keterampilan teknis}

\subsubsection{Perencanaan}

Dalam proses perencanaan program kepala sekolah, kepala sekolah bertindak sebagai koordinator. Kepala sekolah mengundang rapat para pelaku yang berkepentingan dalam rangka menyusun jadwal perencanaan program. Tujuannya yaitu untuk mengidentifikasi standar nasional pendidikan y ang belum tercapai dan strategi pencapaiannya. Sekolah melibatkan guru serta melibatkan masyarakat/orang tua siswa, komite sekolah, peserta didik dan Dinas Pendidikan Kabupaten setempat dalam prosesnya.

Upaya yang dilakukan kepala sekolah dalam mencapai mutu dilakukan dengan menerapkan delapan standar nasional pendidikan. Kepala sekolah membuat Rencana Strategis (Renstra) dan program sekolah yang terdiri dari program jangka pendek, program jangka panjang dan program tahunan. Konteks keterampilan teknisnya yaitu sebagai kepala sekolah merencanakan program sekolah yang diarahkan pada pencapaian standar nasional pendidikan yaitu standar pengelolaan mengenai perencanaan, pelaksanaan, dan pengawasan kegiatan pendidikan pada tingkat satuan pendidikan.

\subsubsection{Pengaturan}

Kepala sekolah melaksanakan fungsi pengaturan dengan memberikan pengarahan, dalam pengembangan dan pengelolaan Rencana Kerja Sekolah(RKS), visi, misi, tujuan dan Rencana Kegiatan dan Anggaran Sekolah (RKAS). Kepala sekolah juga membuat perencanaan program induksi dengan menetapkan sistem prioritas yaitu membenahi hal-hal yang dianggap lebih penting. Selanjutnya, pada proses pengaturan program, kepala sekolah juga menetapkanjadwal 
program dan kegiatan tertentu yang akan dilaksanakan dengan menggunakan sumber daya dan dana yang dimiliki.

Pada pengaturan program, kepala sekolah membuat Surat Keputusan (SK) pembagian tugas kepala sekolah tentang pembagian tugas guru dalam kegiatan proses belajar mengajar dan tugas tambahan tahun pelajaran 2018/2019. Pembagian tugas guru dalam kegiatan proses belajar mengajar melibatkan 20 orang yang terdiri dari kepala sekolah, 11 guru kelas, 2 guru agama, 2 guru olah raga, 1 guru bahasa inggris, 1 guru bahasa daerah, 1 operator sekolah, 1 pustakawan, Dalam proses ini, keterampilan teknis kepala sekolah yaitu sebagai pengatur program yang dilakukan dengan mengarahkan program pada pencapaian standar nasional pendidikan yaitu standar pengelolaan mengenai perencanaan, pelaksanaan, dan pengawasan kegiatan pendidikan pada tingkat satuan pendidikan.

\subsubsection{Koordinasi}

Kepala sekolah mengkoordinasikan program dengan melakukan rapat bersama stakeholders. Kepala sekolah juga melakukan koordinasi dengan bawahan dalam beberapa aspek seperti pengaturan dan pelaksanaan program dengan menyampaikan informasi yang jelas, membangun jaringan informasi yang baik serta menyampaikan profesionalisme guru. Keterampilan teknis kepala sekolah yaitu sebagai koordinator program yang dilakukan dengan mengarahkan program pada pencapaian standar nasional pendidikan yaitu standar pengelolaan mengenai perencanaan, pelaksanaan, dan pengawasan kegiatan pendidikan pada tingkat satuan pendidikan.

\subsubsection{Pengawasan}

Kepala sekolah dalam pengawasan program dengan menggunakan sistem informasi manajemen dan penilaian diri. Pada akhir tahun, guru dan tenaga kependidikan menyerahkan laporan kinerja yang memuat pencapaian dan tujuan yang telah disepakati pada awal tahun ajaran serta melakukan pengawasan secara langsung dan tidak langsung. Dengan demikian, dapat dilihat kelebihan dan kekurangannya. Hal ini positif karena mengarah pada pengembangan perubahan dan perbaikan. Kepala sekolah juga membuat suatu instrumen dan penilaian yang dilihat dari adanya instrumen supervisi perangkat pembelajaran guru di awal tahun. Keterampilan teknis kepala sekolah yaitu sebagai pengawas program yang dilakukan mengarah pada pencapaian standar nasional pendidikan yaitu standar penilaian yang diatur dalam peraturan pemerintah yaitu dengan segala macam mekanisme, prosedur, dan instrumen penilaian. 


\subsubsection{Pengendalian}

Kepala sekolah membuat jadwal pemantauan untuk mengevaluasi program guna mencapai mutu dalam perspektif standar nasional pendidikan secara pembinaan. Selanjutnya, kepala sekolah melakukan tindak lanjut sebagai tindakan koreksi sebagai langkah dalam mencapai perbaikan. Saat pengendalian, peneliti melihat kepala sekolah membuat penilaian prestasi kerja pegawai negeri sipil guna untuk menilai Sasaran Kerja Pegawai (SKP) dan perilaku kerja pegawai selama setahun. Selain itu, peneliti juga meninjau berkas penilaian prestasi kerja pegawai negeri sipil. Konteks keterampilan teknisnya yaitu sebagai evaluator program yang dilakukan mengarah pada pencapaian standar nasional pendidikan yaitu standar penilaian yang diatur dalam peraturan pemerintah yaitu dengan segala macam mekanisme, prosedur, dan instrumen penilaian.

\subsection{Kemampuan membangun hubungan}

\subsubsection{Motivasi}

Motivasi meliputi aktivitas memberikan penghargaan bagi guru yang berprestasi, menanamkan semangat kerja, dan memberikan pembinaan mental, membina guru tentang hal-hal yang berkaitan dengan sikap, karakter dan disiplin untuk meningkatkan mutu kerjanya. Untuk memotivasi bawahan, kepala sekolah mengikutsertakan guru dalam suatu pelatihan dan seminar. Kepala sekolah juga dapat membuat pajangan-pajangan di sekolah yang menginspirasi guru menjadi lebih baik. Kemampuan membangun hubungan yang dilakukan pada aspek ini diarahkan pada pencapaian standar nasional pendidikan yaitu standar pendidik dan tenaga kependidikan yang profesional.

\subsubsection{Semangat/moral}

Kepala sekolah selalu memberi jaringan komunikasi yang berkarakter dan berkualitas serta menciptakan iklim/budaya sekolah yang kondusif. Keadaan ini menunjang terciptanya kondisi pembelajaran yang efektif dan efisien. Kepala sekolah juga selalu memberikan sikap terpuji dan contoh kepada bawahannya dilihat dari keterlibatan langsung kepala sekolah dalam melakukan kerja bakti. Dilihat juga dari hasil pencapaian nilai UN siswa SD Inpres tantu yang rata-rata mendapat nilai tertinggi 97 dan terendah dengan nilai 70. Jumlah siswa secara keseluruhan ada 37 siswa dan dinyatakan lulus 100\%. Dalam hal ini pada konteks kemampuan membangun hubungan yaitu sebagai teladan yang dilakukan mengarah pada pencapaian 
standar nasional pendidikan yaitu standar kompetensi lulu san yaitu kriteria kemampuan lulusan yang mencakup sikap, pengetahuan dan keterampilan.

\section{PEMBAHASAN}

\subsection{Keterampilan konsep}

Keterampilan konsep dibangun dengan menerjemahkan mutu dalam mencapai visi, misi, tujuan dan sasaran serta menyediakan ruang gerak yang leluasa untuk kreativitas dan inovasi sekolah. Kepala sekolah membangun konsep mutu dalam perspektif standar nasional pendidikan dengan menyusun target capaian dalam rencana tindakan. Kemudian, kepala sekolah melakukan perencanaan dan bekerja sama dengan pemangku yang berkepentingan. Hal tersebut sejalan dengan kajian yang dilakukan Fitrah (2017). Menurut dia, kepala sekolah hendaknya tidak hanya memfokuskan perhatian pada pelanggan internal namun juga bekerja sama dengan masyarakat dalam rangka mewujudkan sekolah yang bermutu

Kepala sekolah membuat konsep perencanaan strategis yang melibatkan seluruh guru dan komite sekolah untuk diimplementasikan oleh seluruh stakeholders pendidikan dalam rangka pencapaian fungsi dan tujuan sekolah. Konteks keterampilan konsep yang dilakukan mengarah pada pencapaian standar nasional pendidikan yaitu standar pengelolaan yang berkaitan dengan perencanaan, pelaksanaan, dan pengawasan kegiatan pendidikan pada tingkat satuan pendidikan. Hal serupa dikemukakan Jabbar, dkk. (2016). Keterampilan konsep adalah kemampuan untuk melihat secara utuh dan luas berbagai masalah, kemudian mengaitkannya dan menyelaraskannya dengan berbagai keputusan yang dikeluarkan organisasi dimana individu di dalamnya bekerja bersama untuk meraih tujuan yang telah ditentukan.

Hal tersebut diperkuat oleh hasil studi dokumentasi atau file kelengkapan berkas. Peneliti melakukan pengambilan berkas sertifikat akreditasi A sekolah dan piagam penghargaan kepala sekolah. Pelibatan stakeholders merupakan wujudbahwa sekolahidealnya wajib menyesuaikan dengan kebutuhan pengguna. Hal tersebut sejalan dengan hasil penelitian Nursyifa (2019) yang menyatakan bahwa di era disrupsi saat ini, kepala sekolah hendaknya bersikap demokratis dan mengikuti perubahan.

\subsection{Keterampilan teknis}

\subsubsection{Perencanaan}

Kepala sekolah mengundang rapat para pelaku yang berkepentingan dalam rangka menyusun jadwal perencanaan program untuk mencapai dan menentukan standar nasional pendidikan 
yang belum tercapai. Selanjutnya, kepala sekolah mendiskusikan perencanaan yang berkaitan dengan program-program sekolah yang telah disepakati bersama dengan para pelaku yang berkepentingan. Keterampilan teknis kepala sekolah yaitu merencanakan program yang diarahkan pada pencapaian standar pengelolaan mengenai perencanaan, pelaksanaan, dan pengawasan kegiatan pendidikan pada tingkat satuan pendidikan. Seperti yang dikemukakan oleh Jabbar, dkk. (2016) secara umum perencanaan merupakan proses penetapan tujuan organisasi diikuti strategi (program), taktik (tata cara pelaksanaan program) dan operasi (tindakan) yang diperlukan untuk mencapainya.

Dalam proses perencanaan program, kepala sekolah melibatkan guru dan masyarakat/orang tua siswa, komite sekolah, peserta didik dan dinas pendidikan kabupaten. Upaya yang dilakukan kepala sekolah dalammencapai mutu yaitu dengan menerapkan delapan standar nasional pendidikan. Hasil penelitian memperlihatkan adanya rencana strategis sekolah tahun 2017-2021 disertai program jangka panjang, program jangka pendek serta program tahunan sekolah. Menurut hasil kajian Oman (2017), rencana strategis sekolah adalah salah satu usaha untuk mengontrol sekolah agar tetap efektif dan efisien. Ini mensyaratkan rencana yang mewadahi kebutuhan dan tujuan sekolah untuk jangka waktu tertentu.

\subsubsection{Pengaturan}

Kepala sekolah memberikan pengarahan, melaksanakan pengembangan dan pengelolaan yang baik dan merumuskan RKS, visi, misi dan tujuan sekolah, RKAS serta membuat perencanaan program induksi dengan menggunakan sistem prioritas. Kepala sekolah juga memberikan alokasi waktu yang terjadwal dalam suatu program dan kegiatan tertentu yang akan dilaksanakan dengan menggunakan sumber daya yang ada dan dana yang dimiliki.

Keterampilan teknis kepala sekolah yaitu sebagai pengatur program yang mengarah pada pencapaian standar pengelolaan mengenai perencanaan, pelaksanaan, dan pengawasan kegiatan pendidikan pada tingkat satuan pendidikan. Senada dengan pendapat Stoner (2006), bahwa pengaturan merupakan suatu proses perencanaan, pengorganisasian, kepemimpinan, dan pengendalian upaya dari anggota organisasi serta penggunaan semua sumber daya yang ada pada organisasi untuk mencapai tujuan organisasi yang telah ditetapkan sebelumnya.

\subsubsection{Koordinasi}

Kepala sekolah dalam mengkoordinasikan program melakukan rapat dengan stakeholders. Keterampilan teknisnya yaitu sebagai koordinator program yang mengarahkan pada 
pencapaian standar pengelolaan mengenai perencanaan, pelaksanaan, dan pengawasan kegiatan pendidikan pada tingkat satuan pendidikan. Menurut Handoko(2003:195), koordinasi merupakan proses pengintegrasian tujuan-tujuan dan kegiatan-kegiatan pada satuan-satuan yang terpisah suatu organisasi untuk mencapai tujuan organisasi secara efisien.

Kepala sekolah mengkoordinasikan program dengan guru dan staf dalam rangka pengaturan dan pelaksanaan program dengan menyampaikan informasi yang jelas. Kepala sekolah menyusun pedoman kerja, struktur organisasi, mengelola keuangan serta budaya lingkungan. Koordinasi program kerja dilakukan dengan melihat jadwal kegiatan mulai dari sasaran kerja sampai dengan program kerja. Terkait hal ini, Handoko (2003:196) mengatakan bahwa kebutuhan koordinasi tergantung pada sifat dan kebutuhan komunikasi dalam pelaksanaan tugas dan derajat saling ketergantungan bermacam-macam satuan pelaksananya. Hasil penelitian tersebut senada dengan hasil kajian yang dilakukan oleh Mahardhani (2015) bahwa kepala sekolah yang ideal hendaknya memiliki kemampuan untuk berkomunikasi terhadap pihak internal maupun eksternal karenaprinsip sekolah yang bermutu ditentukan oleh harapan pelanggan internal dan eksternal sekolah.

\subsubsection{Pengawasan}

Kepala sekolah mengemban tugas untuk mengatur lembaga pendidikan yang dipimpin nya agar dapat menjadi maju dan terdepan. Salah satu tugasnya yaitu melakukan pengawasan kepada warga sekolahnya. Pengawasan yang dilakukan oleh kepala sekolah diharapkan akan menghasilkan produktivitas sekolah yaitu mencapai target yang telah direncanakan. Siahaan, Rambe, dan Mahidin (2006:4) menjelaskan bahwa pengawasan diperlukan dalam proses peningkatan mutu pendidikan persekolahan. Asumsinya yaitu setiap orang memerlukan penghargaan dan dorongan dari orang lain dalam bekerja. Tugas dan fungsi kepala sekolah salah satunya adalah memberikan dorongan agar tenaga pendidik dan kependidikan termotivasi untuk berkinerja tinggi.

\subsubsection{Pengendalian}

Kepala sekolah membuat jadwal pemantauan untuk mengevaluasi program pembinaan serta memberikan tindak lanjut untuk perbaikan. Keterampilan teknisnya yaitu sebagai evaluator program yang mengarahkan pada pencapaian standar penilaian yang diatur dalam peraturan pemerintah yaitu dengan segala macam mekanisme, prosedur, dan instrumen penilaian. Pengendalian merupakan bagian dari pengawasan, pengendalian program yang dimaksudkan untuk menjamin tercapainya tujuan dan sasaran pendidikan yang tertuang dalam rencana 
melalui kegiatan-kegiatan koreksi dan penyesuaian selama pelaksanaan rencana tersebut oleh kepala sekolah (Arikunto, 2008).

Kepala sekolah mengendalikan program dengan menghimpun dan menganalisis hasil pemantauan pelaksanaan program sekolah dari masing-masing penanggung jawabnya. Kepala sekolah memberikan tindak lanjut sebagai tindakan koreksi untuk memperbaiki atau mengembalikan segala kegiatan pada tujuan yang seharusnya. Hasil penelitian menunjukkan hal serupa. Kepala sekolah melakukan penilaian prestasi kerja pegawainegeri sipil yang dilihat dari sasaran kerja pegawai (SKP) dan perilaku pegawai.

\subsection{Kemampuan membangun hubungan}

\subsubsection{Motivasi}

Kepala sekolah memotivasi bawahan dengan memberikan penghargaan bagi guru yang berprestasi selalu memberikan pembinaan mental kepada bawahan tentang hal-hal yang berkaitan dengan karakter, sikap, dan disiplin, dan menanamkan kesadaran dalam mengajar dengan mengajak para guru untuk menyadari tugas dan tanggung jawab sebagai guru. Kemampuan membangun hubungan diindikasikan dari kemampuan kepala sekolah sebagai motivator yang mengarahkan guru bekerja profesional untuk menunjang keberhasilan pencapaian tujuan pendidikan.

Senada dengan yang dikemukakan oleh Mulyasa (2005) bahwa motivasi merupakan tenaga pendorong tingkah laku ke arah pencapaian suatu tujuan tertentu. Seseorang akan bersungguh-sungguh bekerja ketika memiliki dorongan dan motivasi yang tinggi. Hasil penelitian menunjukkan bahwa kepala sekolah telah membangun motivasi bawahan yang dibuktikan dengan berkas surat izin guru untuk mengikuti pelatihan dan seminar.

\subsubsection{Semangat/moral}

Pada penelitian ini, kemampuan membangun semangat atau moral yaitu kemampuan kepala sekolah menjadi teladan guru dalam proses pencapaian standar nasional Pendidikan. Chaplin (1989) menjelaskan bahwa moral mengacu pada akhlak yang sesuai dengan peraturan sosial, menyangkut hukum atau adat kebiasaan yang mengatur tingkah laku, sikap dan perbuatan setiap individu terhadap kehidupan orang lain. 


\section{SIMPULAN}

Kepala SD Inpres menunjukkan penguasaan keterampilan manajerial dalam proses peningkatan mutu pendidikan di sekolahnya. Keterampilan ini meliputi keterampilan konsep, teknis, dan membangun hubungan. Keterampilan konsep di bangun dengan menerjemahkan mutu ke dalam visi, misi, tujuan dan sasaran sekolah serta menyediakan ruang gerak yang leluasa bagi guru untuk kreatif dan inovatif. Keterampilan teknis dilihat dari kemampuan kepala sekolah merencanakan, mengatur, mengkoordinasikan kegiatan, mengawasi, dan mengendalikan program. Keterampilan membangun hubungan meliputi kemampuan motivasi dan memberi semangat/moral kepada bawahan .

\section{Acknowledgement}

Penulis ucapkan terima kasih kepada seluruh pihak yang telah membantu proses penelitian ini berjalan.

\section{DAFTAR PUSTAKA}

Arikunto, S. (2008). Evaluasi program pendidikan. PT Bumi Aksara. https://doi.org/10.1109/TEVC.2004.826389

Atmodiwirio, S. (2014). Manajemen pelatihan. Jakarta: Ardadizya Jaya.

Chaplin, C. P. (1989). Kamus lengkap psikologi. Jakarta: Rajawali Press.

Data Pokok Pendidikan Dasar dan menengah Direktorat Jenderal Pendidikan dasar dan Menengah Kementerian Pendidikan dan Kebudayaan. (n.d.). Retrieved from http://dapo.dikdasmen.kemdikbud.go.id/sekolah/.

Fitrah, M. (2017). Peran kepala sekolah dalam meningkatkan mutu pendidikan. Jurnal Penjaminan Mutu. https://doi.org/10.25078/jpm.v3i1.90

Handoko, T. H. (2003). Manajemen edisi 2. Yogyakarta: BPFE.

Jabbar, C. S. A., dkk. (2016). Manajemen pendidikan. Yogyakarta: UNY Press.

Mahardhani, A. J. (2015). Kepemimpinan ideal kepala sekolah. Jurnal Dimensi Pendidikan dan Pembelajaran.

Moleong, L. J. (2018). Metodologi penelitian kualitatif. Bandung: PT Remaja Rosdakarya.

Miles, M. B., Huberman, A. M., \& Saldana, J. (2014). Qualitative data analysis: a methods sourcebook. Thousand Oaks: SAGE Publications, Inc.

Mulyasa, E. (2005). Menjadi guru profesional menciptakan pembelajaran kreatif dan menyenangkan. In Bandung: Remaja Rosdakarya.

Nursyifa, A. (2019). Kepemimpinan kepala sekolah dalam menghadapi era revolusi industri 4.0: perspektif sosiologi pendidikan. Jurnal Pendidikan Kewarganegaraan. https://doi.org/10.32493/jpkn.v6i2.y2019.p143-154 
Oman, Faturohman. (2017). Faktor kunci keberhasilan komponen penyusunan manajemen perencanaan strategis sekolah. Tarbawi: Jurnal Keilmuan Manajemen Pendidikan, 3(01), 77-89.

Kementerian Pendidikan dan Kebudayaan. (2016). Peraturan Menteri Pendidikan dan Kebudayaan nomor 20 tahun 2016 tentang standar kompetensi lulusan pendidikan dasar dan Menengah.

Kementerian Pendidikan dan Kebudayaan. (2016). Peraturan Menteri Pendidikan dan Kebudayaan Nomor 22 tahun 2016 tentang standar proses pendidikan dasar dan menengah.

Kementerian Pendidikan dan Kebudayaan. (2018). Peraturan Menteri Pendidikan dan Kebudayaan Nomor 6 Tahun 2018 tentang penugasan guru.

Peraturan Pemerintah Republik Indonesia Nomor 13 Tahun 2015. Retrieved from http://elibrary.dprd.jatengprov.go.id/peraturan-pemerintah-republik-indonesia-nomor13-tahun-2015.

Peraturan Pemerintah Republik Indonesia Nomor 32 Tahun 2013 Tentang Perubahan Atas Peraturan Pemerintah No.19 Tahun 2005 Tentang Standar Nasional Pendidikan.

Siahaan, A., Rambe, A., \& Mahidin. (2006). Manajemen pengawas pendidikan. Ciputat: Quantum Taching.

Stoner, A. F. (2006). Manajemen sumber daya manusia. Jakarta: Bumi Aksara.

Undang-Undang Nomor 20 Tahun 2003 tentang Sistem Pendidikan Nasional 